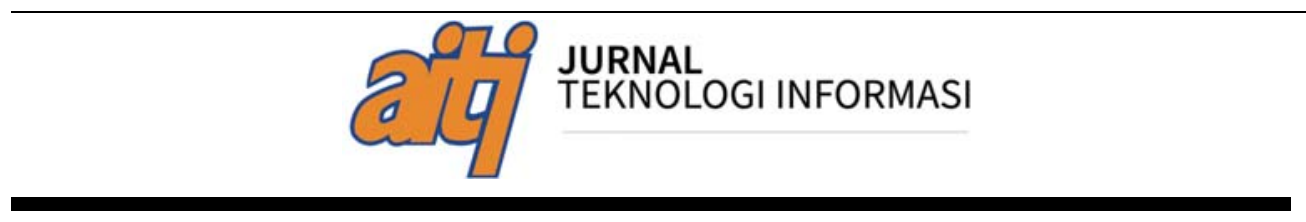

\title{
Penerapan Algoritma Fuzzy C-Means Pada Penentuan Lokasi Gudang Pendukung PT. XYZ
}

\author{
Brian Christian, Lukman Hakim \\ Teknik Informatika, Universitas Bunda Mulia \\ Jakarta- Indonesia \\ Email : brianxca7@gmail.com,1hakim@bundamulia.ac.id
}

\begin{abstract}
In data mining a series of processes are applied to extract information from a data set. PT. $X Y Z$ which has a lot of sales data that can be processed. In the company PT. XYZ which is engaged in the retail sector which has tight competition and develops rapidly, customer satisfaction is one of the things that need to be considered. It takes more than product quality, but service to customers is also important to win competition in sales and one that can be considered in customer satisfaction is the availability of products that customers want. Use of Clustering Method to classify objects based on similarity in characteristics, especially one of fuzzy clustering, that is, fuzzy C-means can be used to determine the distance and presence of each point in a cluster. In this study, fuzzy C-means is applied in determining the supporting warehouse of PT. XYZ is based on the clustering location of $P T . X Y Z$ which is represented as the Cartesian coordinates and the centroid of each cluster refers to the location of the supporting warehouse along with the grouping of outlets with the supporting warehouse.Using 3 clusters in 100 iterations the difference in objective function is $3.3 e-8 \%$, while the experiment using 4 clusters requires 39 iterations with an objective function difference of $1.1 e-12 \%$,then themore number of clusters will minimize the difference in objective functions for results with smaller errors.
\end{abstract}

Keywords: Data Mining, Clustering, Fuzzy C-Means, Supporting Warehouse PT. XYZ

\section{Pendahuluan}

Pelayanan kepada pelanggan sangat diutamakan perusahaan-perusahaan bersamaan dengan produk yang dijual. Persaingan antar perusahaan khususnya di bidang retail memperhatikan bukan hanya mutu dari produknya tetapi pelayanan kepada pelanggan dalam jangka waktu panjang. Salah satu perusahaan yang bergerak dalam bidang ini adalah PT. XYZ. Kualitas produk bukanlah menjadi satu-satunya bagi perusahaan itu untuk mampu bersaing, terlebih bagi perusahaan yang menjual produk yang sama dan berada pada harga yang sama. Ketersediaan barang yang dijual perlu diperhatikan untuk kenyamanan pelanggan danAdapun kendala dalam ketersediaan barang yang dijual pada di gerai PT. XYZ dikarenakan jarak yang cukup jauh untuk mengirimkan persediaan barang atau distribusi barang ke gerai yang ada, untuk itu diperlukan sejumlah gudang pendukung yang berjarak 
cukup dekat dengan gerai yang ada disekitar untuk mempermudah distribusi persediaan barang serta keperluan pelanggan terhadap produk yang berbeda beda. Oleh karena itu diperlukan solusi untuk memudahkan distribusi barang dan menjaga persediaan barang agar selalu tersedia untuk pelanggan. Salah satu cara yang dapat dilakukan adalah PT. XYZ membuka gudang pendukung yang berada di tempat dengan jarak yang lebih dekat dengan cabang-cabang gerai PT. XYZ.

Berdasarkan permasalahan tersebut, dapat dirumuskan masalah "bagaimana mengelompokkan gerai PT. XYZ agar terbentuk kelompok-kelompok gerai yang memiliki jarak terdekat pada lokasi tertentu yang dapat dijadikan sebagai tempat gudang pendukung PT. XYZ”. Dalam penelitian ini akan dikaji pengelompokkan gerai dengan menggunakan algoritma Fuzzy C-Meansuntuk membentuk klaster sebagai dasar menentukan lokasi gudang pendukung PT. XYZ.

Tujuan penelitian ini adalah membentuk klaster dengan menggunakan Fuzzy C-Means untuk menentukan lokasi gudang pendukung PT. XYZ. Data yang digunakan dalam penelitian ini adalah data gerai PT. XYZ dalam 10 tahun terakhir.

\section{Kajian Pustaka}

\section{A. Data Mining}

Data mining (DM) adalah serangkaian proses untuk menggali nilai tambah dari suatu kumpulan data berupa pengetahuan yang selama ini tidak diketahui secara manual. Patut diingat bahwa kata mining sendiri berarti usaha untuk mendapatkan sedikit barang berharga dari sejumlah besar material dasar. Karena itu DM sebenarnya memiliki akar yang panjang dari bidang ilmu seperti kecerdasan buatan (artificial intelligent), machine learning, statistik dan basis data. Beberapa teknik yang sering disebut-sebut dalam literatur DM antara lain: clustering, classification, association rule mining, neural network, dan genetic algorithm[1].

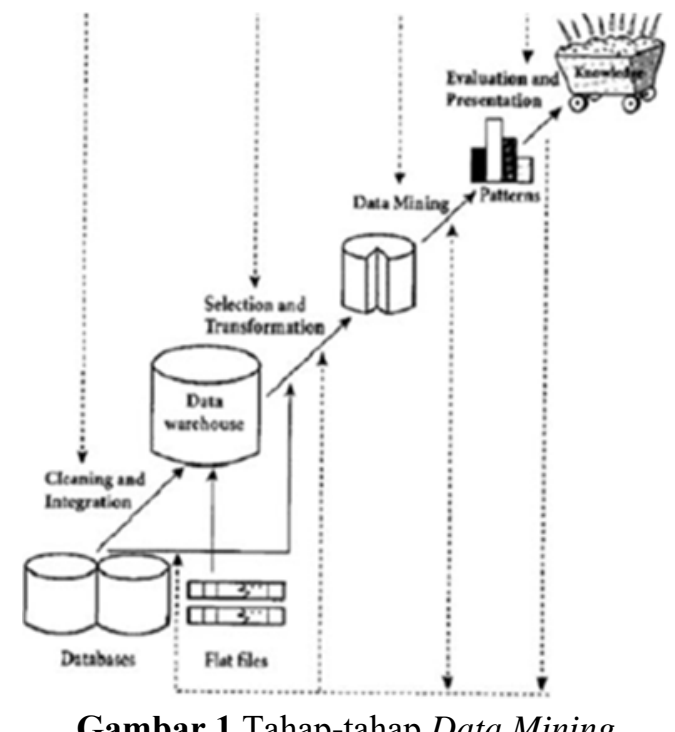

Gambar 1 Tahap-tahap Data Mining 
AITI: Jurnal Teknologi Informasi

Data mining dapat dibagi menjadi beberapa tahap. Tahap-tahap tersebut bersifat interaktif di mana pemakai terlibat langsung atau dengan perantaraan knowledge base. Tahap-tahap ini antara lain[2]:

1. Pembersihan data (untuk membuang data yang tidak konsisten dan noise)

2. Integrasi data (penggabungan data dari beberapa sumber)

3. Transformasi data (data diubah menjadi bentuk yang sesuai untuk dimining)

4. Aplikasi teknik DM

5. Evaluasi pola yang ditemukan (untuk menemukan yang menarik/bernilai)

6. Presentasi pengetahuan (dengan teknik visualisasi).

\section{B. Clustering}

Clustering adalah proses pengelompokan benda serupa ke dalam kelompok yang berbeda, atau lebih tepatnya partisi dari sebuah data set kedalam subset, sehingga data dalam setiap subset memiliki arti yang bermanfaat. Sebuah cluster terdiri dari kumpulan benda-benda yang mirip antara satu dengan yang lainnya dan berbeda dengan benda yang terdapat pada cluster lainnya. Algoritma clustering terdiri dari dua bagian yaitu secara hirarkis dan secara partitional. Algoritma hirarkis menemukan cluster secara berurutan dimana cluster ditetapkan sebelumnya, sedangkan algoritma partitional menentukan semua kelompok pada waktu tertentu [1]. Prinsip dari clustering adalah memaksimalkan kesatuan antar anggota satu klaster dan meminimumkan kesamaan antar klaster. Algoritma clustering merupakan algoritma pengelompokan sejumlah data menjadi kelompokkelompok data tertentu. Objek data yang terletak dalam satu klaster harus mempunyai kemiripan, sedangkan yang tidak berada dalam satu klaster tidak mempunyai kemiripan [3]. Dalam clustering metode ini berusaha untuk menempatkan obyek yang mirip (jaraknya dekat) dalam satu cluster dan membuat jarak antar cluster sejauh mungkin [4].

\section{Fuzzy Clustering}

Fuzzy clustering adalah suatu teknik untuk menentukan klaster yang didasarkan pada jarak menggunakan fungsi keanggotaan fuzzy. Derajat keanggotaan fungsinya merupakan jarak antara suatu himpunan fuzzy dengan suatu himpunan crisp terdekat. Ada 3 cara untuk mencari jarak tersebut yaitu[3]:

1. Hamming distance

$$
\begin{aligned}
& f(A)=\sum\left[\mu_{A}[x]-\mu_{C}[\right. \\
& \text { atau } \\
& f(A)=\sum \min \left[\mu_{A}[x], 1-\mu_{A}[\right.
\end{aligned}
$$

2. Euclidean distance

$$
f(A)=\left\{\sum\left[\mu_{A}[x]-\mu_{C}[x]\right]^{2}\right\}
$$




\section{Minkowski distance}

$$
f(A)=\left\{\sum\left[\mu_{A}[x]-\mu_{C}[x]\right]^{w}\right\}^{1}
$$

\section{Fuzzy C-Means}

Fuzzy C-Means adalah metode pengelompokan data yang diusulkan oleh Bezdek dengan memanfaatkan konsep dari fuzzy theory [5]. Fuzzy C-Means menerapkan pengelompokan fuzzy, dimana setiap data dapat menjadi anggota dari beberapa cluster dengan derajat keanggotaan yang berbeda-beda pada setiap cluster. Fuzzy C-Means merupakan algoritma iteratif, yang menerapkan iterasi pada proses clustering data. Tujuan dari Fuzzy C-Means adalah untuk mendapatkan pusat cluster yang nantinya akan digunakan untuk mengetahui data yang masuk ke dalam sebuah cluster.

Dalam Fuzzy C-Means, setiap data memiliki derajat keanggotaan dalam setiap kelompok. Derajat keanggotaan tersebut memiliki nilai diantara 0 dan 1 . Suatu data memiliki derajat keanggotaan sama dengan 0 jika data tersebut sama sekali tidak menjadi bagian dalam sebuah kelompok. Sementara nilai 1 menunjukkan bahwa data merupakan anggota sepenuhnya dalam suatu kelompok. Hal tersebut merupakan perbedaan utama denganalgoritma 'hard clustering', seperti K-means, dimana suatu data merupakan anggota suatu kelompok atau tidak. Seperti halnya dalam algoritma K-means [6], Fuzzy C-Means memiliki titik pusat(centroid) kelompok serta menentukan derajat keanggotaan untuk setiap data i pada kelompok j. Algoritma Fuzzy C-Means memiliki fungsi objektif dengan meminimalkan fungsi pada persamaan[7]:

$$
f(A)=\sum_{i=1}^{N} \sum_{j=1}^{C}\left(\mu_{i j}\right)^{w} \| x_{i}-c_{j}
$$

Fungsi objektif pada persamaan di atas digunakan untukmeminimalkan jarak antar data dalam kelompok yang sama (intra-cluster) sehingga suatu data memiliki kemiripandengan data lain pada kelompok yang sama. Nilai w adalah nilai bobot yang diperkenalkan dalam algoritma Fuzzy C-Means. Nilai w $>1$ dan umumnya diberikan nilai 2. Berikut ini merupakan tahapan dari algoritma Fuzzy $C$ Means[8]:

1. Menentukan data yang akan di klaster $X$, berupa matriks berukuran $n \times m$ ( $n=$ jumlah sampeldata, $m=$ atribut setiap data). $X_{i j}=$ data sampel ke- $i$ $(i=1,2, \ldots, n)$, atribut ke-j $(j=1,2, \ldots, m)$.

2. Tentukan jumlah cluster (c), pangkat ( $w$ ), maksimum iterasi (MaxIter), error terkecil yangdiharapkan $(\zeta)$, fungsi obyektif awal $\left(P_{0}=0\right)$, iterasi awal $(t=1)$. Inisialisasi pusat kelompok secara acak, $C 1, C 2, \ldots, C k$.

3. Inisialisasi derajat keanggotaan, dan bangkitkan bilangan random, $i=1,2, \ldots, n$; $j=1,2, \ldots, c$; sebagai elemen-elemen matriks partisi, dengan $1 \leq i \leq n$ dan $1 \leq$ $j \leq n$. Derajat keanggotaan yang merujuk pada seberapa besar kemungkinan suatu data bisa menjadi anggota ke dalam suatu cluster [new2][9].

4. Hitung titik pusat kelompok,

$$
C_{j}=\frac{\sum_{i=1}^{n}\left(\mu_{i j}\right)^{w} x i}{\sum_{i=1}^{n}\left(\mu_{i j}\right)^{w}}
$$


AITI: Jurnal Teknologi Informasi

Volume 16 No. 1 Februari 2019, 31-48

dimana: $n=$ jumlah data dalam kelompok $\mathrm{j}, x i=$ data ke- $i, \mu_{i j}=$ derajat keanggotaan data $i$ pada kelompok $j$

5. Perbarui derajat keanggotaan,

$$
C_{i j}=\frac{D\left(x_{i}, c_{k}\right)^{\frac{-1}{w-1}}}{\sum_{k=1}^{c} D\left(x_{i}, c_{k}\right)^{\frac{-1}{w-1}}}
$$

dimana: $D(x, c)$ adalah jarak antara data $x$ ke titik pusat kelompok $c$ yang diperoleh menggunakan rumus Euclidian yang merupakan nilai jarak antara klaster terhadap pusat klaster [1][3].

$$
D(x, y)=\sqrt{\sum_{i=1}^{n}\left(x_{i}-y_{i}\right)^{2}}
$$

6. Hitung fungsi objektif pada persamaan 5

7. Lakukan langkah 5, 6, 7 sehingga tidak ada perubahan signifikan pada fungsi objektif atau tahapan iterasi maksimal sudah terpenuhi.

\section{E. Sistem Koordinat Kartesius}

Dalam Matematika, suatu sistem koordinat Kartesius pada umumnya digunakan untuk menentukan tiap titik dalam bidang dengan menggunakan dua bilangan yang biasa disebut koordinat $x$ dan koordinat $y$ dari titik tersebut. Untuk mendefinisikan koordinat diperlukan dua garis berarah yang tegak lurus satu sama lain (sumbu $x$ dan sumbu $y$ ), dan panjang unit, yang dibuat tanda-tanda pada kedua sumbu tersebut, seperti terdapat pada gambar 2[10].

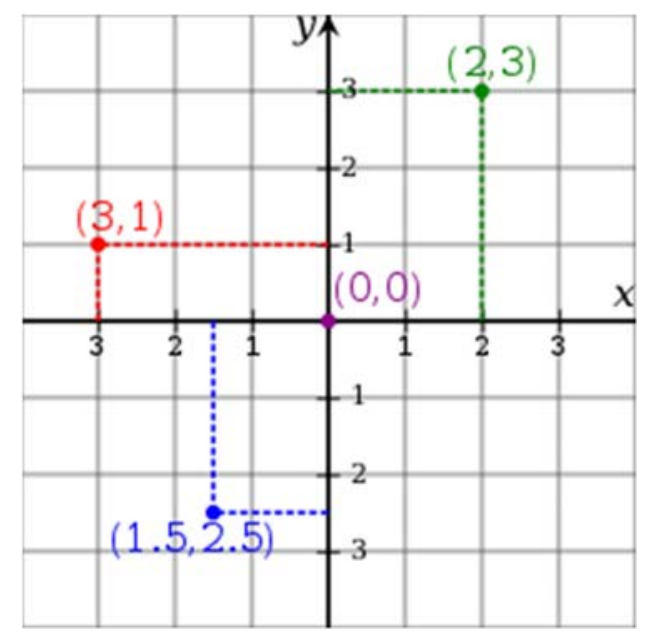

Gambar 2. Sistem Koordinat Kartesius

Istilah Kartesius tersebut digunakan untuk mengenang ahli Matematika sekaligus filsuf dari Perancis Descartes, yang sangat berperan besar dalam menggabungkan aljabar dan geometri (Cartesius adalah latinisasi untuk Descartes). Hasil kerjanya sangat berpengaruh dalam perkembangan geometri analitik, kalkulus dan kartografi. Ide dasar sistem ini dikembangkan pada tahun 1637 dalam 
dua tulisan karya Descartes. Pada bagian kedua dari tulisannya Discourse on Method, ia memperkenalkan ide baru untuk menggambarkan posisi titik atau obyek pada sebuah permukaan, dengan menggunakan dua sumbu yang bertegak lurus antar satu dengan yang lain. Sedangkan dalam tulisannya yang lain, La Géométrie, ia memperdalam konsep-konsep yang telah dikembangkannya tersebut[11].

\section{Metode Penelitian}

Penelitian ini adalah penelitian eksperimen dengan tahapan sebagai berikut:

\section{Pengumpulan data}

Data yang digunakan adalah data cabang gerai PT. XYZ berupa data alamat tempat gerai. Data ini diambil dari PT. XYZ sejumlah 200 sebagai sample.

Pre-Processing

Pada tahap pre-processing dilakukan data integration dan data transformation. Data integration yaitu proses menggabungkan data dari banyak database dalam hal ini adalah data pelanggan PT. XYZ dari berbagai kecamatan di Jabodetabek. Data transformation dilakukan untuk mengubah bentuk dan format data. Hal ini tentunya sangat membantu memudahkan pengguna dalam proses mining ataupun memahami hasil yang didapat [5]. Dalam pre-processing sekumpulan data lokasi gerai PT. XYZ diubah menjadi data lokasi menggunakan koordinat kartesius.

Clustering

Pada tahap ini, algoritma yang digunakan adalah algoritma fuzzy c-means. Percobaan dilakukan berulang-ulang dengan menggunakan Matlab hingga diperoleh nilai optimal, yaitu nilai dimana nilai centroid tidak mengalami perubahan.

Tahapan penelitian seperti yang sudah diuraikan di atas ditunjukkan pada gambar 3 .

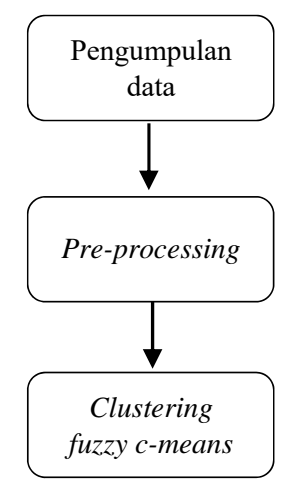

Gambar 3. Tahap Penelitian

\section{A. Pengumpulan Data}

Penelitian menggunakan fuzzy c-means untuk menentukan lokasi gudang pendukung memerlukan sejumlah data alamat gerai PT. XYZ. Data yang diperoleh 
AITI: Jurnal Teknologi Informasi

Volume 16 No. 1 Februari 2019, 31-48

dari PT. XYZ berupa data mentah yang perlu diproses kembali agar dapat digunakan dengan pre-processing. Sebagian data dari PT. XYZ yang disusun dalam Tabel 1.

Tabel 1 Sample data Toko PT. XYZ

\begin{tabular}{|c|c|c|}
\hline Kode & Nama & Alamat \\
\hline \multirow[t]{3}{*}{ A004 } & PASAR SEGAR & JL. RAYA GRAHA BUNGA DA 17-19 \\
\hline & BINTARO & KEL.PD.JAGUNG TIMUR KEC.SERPONG \\
\hline & & UTARA_TANGERANG \\
\hline \multirow[t]{2}{*}{ A017 } & DUTA BINTARO & JL.DUTA BINTARO BOK.F1 NO.11 RT.01/10 \\
\hline & $2(\mathrm{~F})$ & KEL.KUNCIRAN KEC.PINANG KAB.TANGERANG \\
\hline \multirow[t]{2}{*}{ A045 } & RUKO BUKIT & RUKO BUKIT DAGO, RT. 06, RW. 14, BLOK AA \\
\hline & DAGO (F) & $\begin{array}{c}\text { NO. } 5 \& 6 \text {, DESA RAWA BELONG, KEC. GUNUNG } \\
\text { SINDUR, KAB. BOGOR }\end{array}$ \\
\hline \multirow[t]{2}{*}{ A046 } & CEGER RAYA & JL.CEGER RAYA RT.002 RW.04 \\
\hline & & $\begin{array}{c}\text { KEL.JURANGMANGU TIMUR, KEC.PONDOK } \\
\text { AREN TANGERANG }\end{array}$ \\
\hline \multirow[t]{3}{*}{ A047 } & ARINDA & JL.RAYA CEGER PONDOK AREN/PERUM \\
\hline & PERMAI & ARINDA PERMAI BLOK B/2 RT.04 \\
\hline & & $\begin{array}{c}\text { RW.04, KEL.PONDOK AREN ,KEC.PONDOK AREN } \\
\text { TANGERANG }\end{array}$ \\
\hline \multirow[t]{2}{*}{ A048 } & VILLA JAPOS (F) & $\begin{array}{l}\text { JAPOS GRAHA LESTARI BLOK A1/11 RT. } 09 \text { RW. } \\
08 \text { KEL. JURANGMANGU KEC. PONDOK AREN }\end{array}$ \\
\hline & & TANGERANG \\
\hline \multirow[t]{2}{*}{ A049 } & PONDOK & JL. PONDOK BETUNG RAYA NO.6 KEL. PONDOK \\
\hline & $\begin{array}{l}\text { BETUNG RAYA } \\
(\mathrm{F})\end{array}$ & KARYA , KEC. PONDOK AREN TANGERANG \\
\hline \multirow[t]{2}{*}{ A050 } & PONDOK JAYA & JL. PONDOK JAYA, RT.003, RW. 03, KEL. PONDOK \\
\hline & & JAYA, KEC. PONDOK AREN, KAB. TANGERANG \\
\hline \multirow[t]{2}{*}{ A051 } & PONDOK JATI & $\begin{array}{l}\text { JL. JAPOS RAYA RT. } 005 \text { RW. } 04 \text { KEL. JURANG } \\
\text { MANGU BARAT KEC. PONDOK AREN }\end{array}$ \\
\hline & & TANGERANG \\
\hline A052 & $\begin{array}{l}\text { PONDOK AREN / } \\
\text { CEGER RAYA } 2\end{array}$ & $\begin{array}{l}\text { JL. CEGER RAYA RT. 02/01 KEL. PONDOK AREN } \\
\text { KEC. PONDOK AREN TANGERANG }\end{array}$ \\
\hline A053 & WAHID HASYIM & $\begin{array}{l}\text { JL. KH. WAHID HASYIM NO. } 41 \text { RT. } 005 \text { RW. 06, } \\
\text { JURANG MANGU TIMUR, PONDOK AREN }\end{array}$ \\
\hline \multirow[t]{2}{*}{ A054 } & PONDOK AREN 2 & JL PONDOK AREN RAYA RT 03/01 \\
\hline & & $\begin{array}{c}\text { KEL.PONDOK AREN KEC.PONDOK AREN } \\
\text { TANGERANG }\end{array}$ \\
\hline A055 & WAHID HASYIM - 2 & $\begin{array}{l}\text { JL. KH. WAHID HASYIM, RT. 003, RW. 004, } \\
\text { KEL. JURANGMANGU TIMUR, KEC. PONDOK } \\
\text { AREN, TANGERANG }\end{array}$ \\
\hline A056 & SERPONG PARK & $\begin{array}{c}\text { JL. LENGKONG RAYA BLOK P1 NO.8 \& } 9 \text { KEL. } \\
\text { LENGKONG KARYA, KEC. SERPONG } \\
\text { TANGERANG }\end{array}$ \\
\hline
\end{tabular}




\begin{tabular}{|c|c|c|}
\hline Kode & Nama & Alamat \\
\hline A058 & THE GREEN & $\begin{array}{c}\text { KOMP. PERUMAHAN THE GREEN B } 7 \text { NO. 5, } \\
\text { KEL. CILENGGANG, KEC. SERPONG, KAB. } \\
\text { TANGERANG }\end{array}$ \\
\hline A059 & $\begin{array}{l}\text { EKA HOSPITAL } \\
(\mathrm{CONV})\end{array}$ & $\begin{array}{l}\text { LOBBY EKA HOSPITAL,CENTRAL BUSINESS } \\
\text { DISTRICT LOT IX KEL.LENGKONG GUDANG } \\
\text { BARAT KEC.SERPONG KAB.TANGERANG }\end{array}$ \\
\hline A060 & $\begin{array}{l}\text { GRIYA HIJAU } \\
\text { RAYA (F) }\end{array}$ & KOMP. GRIYA HIJAU RAYA NO.25 \& 27 \\
\hline A061 & JELUPANG UTAMA & $\begin{array}{c}\text { JL. JELUPANG UTAMA, RT. 005, RW. 02, KEL. } \\
\text { JELUPANG, KEC. SERPONG UTARA, KAB. } \\
\text { TANGERANG }\end{array}$ \\
\hline A062 & $\begin{array}{c}\text { PERUM GRIYA } \\
\text { ASRI }\end{array}$ & $\begin{array}{c}\text { JL. PERUM GRIYA ASRI BLOK B3/14 RT. } \\
\text { 055/007 ,KEL. JELUPANG, KEC. SERPONG, } \\
\text { TANGERANG }\end{array}$ \\
\hline A063 & $\begin{array}{l}\text { VILLA MUTIARA } \\
\text { SERPONG }\end{array}$ & $\begin{array}{l}\text { PERUM VILLA MUTIARA SERPONG BLOK A } \\
\text { 01- } 08 \text { B \& C RT.005 RW.011 KEL.PONDOK } \\
\text { JAGUNG TIMUR , KEC.SERPONG TANGERANG }\end{array}$ \\
\hline A064 & REMPOA & JL. PAHLAWAN RAYA RT.3/4 NO 99A REMPOA \\
\hline A065 & $\begin{array}{c}\text { GEREJA BINTARO } \\
\text { BARU }\end{array}$ & $\begin{array}{c}\text { JL.GEREJA BINTARO SEKTOR } 2 \text { SH 2/8 RT.007 } \\
\text { RW.007 KEL.RENGAS , KEC.CIPUTAT } \\
\text { TANGERANG }\end{array}$ \\
\hline A066 & LEGOSO & $\begin{array}{l}\text { JL.LEGOSO RAYA NO.25 RT.004 RW.007 } \\
\text { KEL.PISANGAN KEC.CIPUTAT TANGERANG }\end{array}$ \\
\hline A067 & $\begin{array}{l}\text { CIREUNDEU } \\
\text { RAYA }\end{array}$ & $\begin{array}{l}\text { JL.CIREUNDEU RAYA RT.001 RW.001 } \\
\text { KEL.CIREUNDEU KEC.CIPUTAT TANGERANG }\end{array}$ \\
\hline A068 & $\begin{array}{c}\text { RAYA } \\
\text { PAHLAWAN }\end{array}$ & $\begin{array}{l}\text { JL.PAHLAWAN RAYA CEMPAKA PUTIH / GANG } \\
\text { ARSENTO RT.005 RW.001 KEL.CEMPAKA PUTIH, } \\
\text { KEC. CIPUTAT TANGERANG }\end{array}$ \\
\hline A070 & CIREUNDEU 2 & $\begin{array}{c}\text { JL.CIREUNDEU RAYA RT.001 RW.06 } \\
\text { KEL.CIREUNDEU, KEC.CIPUTAT TANGERANG }\end{array}$ \\
\hline
\end{tabular}

Adapun data mengenai lokasi gerai dalam koordinat kartesius didapatkan menggunakan Google Maps dengan alamat toko dari data PT. XYZ.

\section{B. Fuzzy C-Means}

Pada penelitian ini akan menggunakan metode Clustering dengan algoritma Fuzzy C-means. Metode ini memberikan hasil analisis yang berdasarkan pada data gerai atau toko PT. XYZ.Proses clustering yang dilakukan akan mengelompokkan data gerai dan mendapatkan pusat masing masing klaster untuk menentukan posisi gudang pendukung PT. XYZ.Gambar 4 menunjukkan flowchart algoritma fuzzy cmeans. 
AITI: Jurnal Teknologi Informasi

Volume 16 No. 1 Februari 2019, 31-48

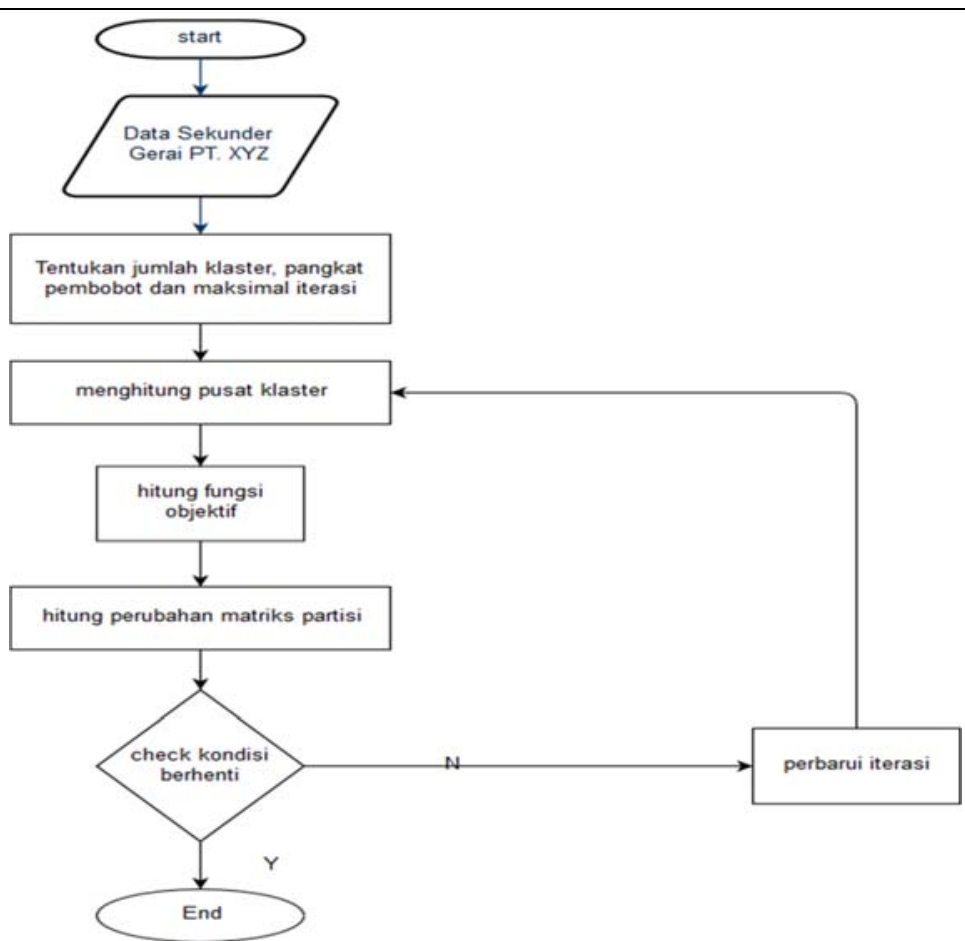

Gambar 4. Flowchart fuzzy c-means

\section{Rancangan Tampilan}

Rancangan tampilan antarmuka yang diperlukan adalah menu utama yang berisikan form masukan untuk memasukkan data inisialisasi parameter awal. Berikut rancangan tampilan antarmuka menu utama:

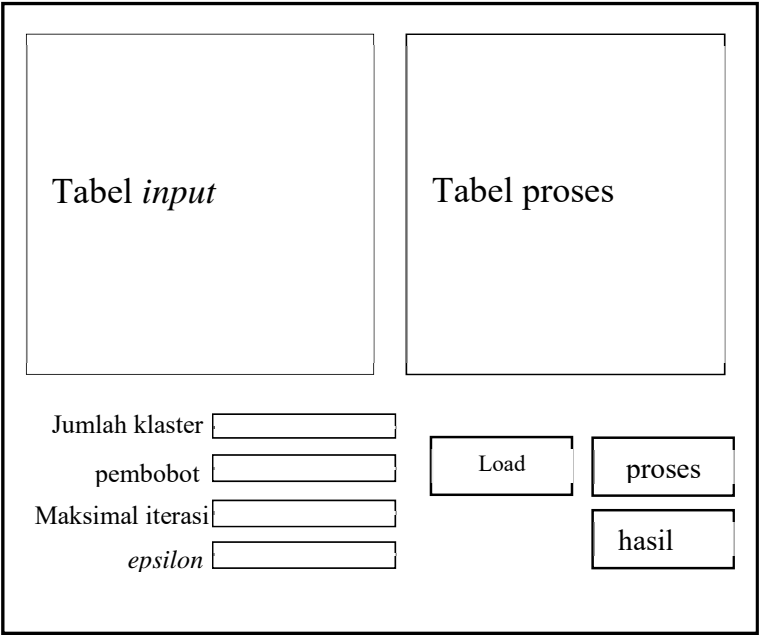

Gambar 5. Antarmuka Utama

Terdapat beberapa komponen antarmuka seperti button load data untuk menggunakan data yang terdapat dari file yang akan digunakan dalam proses, button hasil untuk menampilkan hasil berupa plot data atau grafik yang menunjukkan pengelompokkan dan grafik perubahan fungsi objektif, button proses 
digunakan untuk menjalankan proses fuzzy c-means dengan data yang telah masukkan.

\section{Hasil dan Pembahasan}

Dalam penelitian ini lokasi gudang pendukung PT. XYZ akan ditentukan dengan clustering menggunakan fuzzy c-means. Data yang digunakan dalam penelitian ini adalah data gerai atau toko PT. XYZ yang tersebar dibeberapa lokasi dan penjualan tiap gerai dalam kuartal kedua tahun 2017. Data lokasi gerai diubahkan kedalam koordinat kartesius pada peta yang memiliki sumbu $x$ dan sumbu $y$. Koordinat ini yang digunakan untuk menentukan centroid dari klaster yang menjadi lokasi untuk mendirikan gudang pendukung.

Sebelum melakukan perhitungan fuzzy c-means, terlebih dahulu data yang akan dipakai dalam perhitungan disiapkan dan dimasukkan ke dalam program. Data yang dimasukkan adalah data sekunder yang telah dinormalisasi yang kemudian dimasukkan melalui form masukkan. Kemudian lakukan proses clustering dengan fuzzy c-means.

\section{A. Perhitungan fuzzy c-means}

Fuzzy c-means memiliki tahapan untuk melakukan clustering seperti yang telah diilustrasikan pada flowchart pada gambar 3 sebelumnya.

1. Menentukan matriks:

Setelah data yang akan dihitung tersedia dan telah dimasukkan maka matriks berukuran $\mathrm{n} \times \mathrm{m}$ dimana $\mathrm{n}$ merupakan jumlah sampel data dan $\mathrm{m}$ adalah atribut setiap data dapat ditentukan. Berikut sebagian dari 200 sample data yang diproses

Tabel 2. Sample matriks

\begin{tabular}{crr}
\hline No & \multicolumn{1}{c}{$\boldsymbol{X}$} & \multicolumn{1}{c}{$\boldsymbol{Y}$} \\
\hline 1 & 83.72 & 16.45 \\
2 & 75.35 & 94.81 \\
3 & 100.31 & 92.92 \\
4 & 29.88 & 80.76 \\
5 & 23.47 & 57.90 \\
6 & 26.09 & 22.62 \\
7 & 1.04 & 69.53 \\
8 & 63.08 & 62.70 \\
9 & 56.45 & 35.87 \\
10 & 72.03 & 14.13 \\
11 & 88.79 & 95.88 \\
12 & 33.78 & 5.24 \\
13 & 3.88 & 51.82 \\
\hline
\end{tabular}


AITI: Jurnal Teknologi Informasi

Volume 16 No. 1 Februari 2019, 31-48

\begin{tabular}{crc}
\hline No & \multicolumn{1}{c}{$\boldsymbol{X}$} & $\boldsymbol{Y}$ \\
\hline 14 & 43.49 & 35.46 \\
15 & 3.92 & 37.00 \\
\hline
\end{tabular}

\section{Inisialisasi Parameter Awal}

Algoritma fuzzy c-means memerlukan parameter awal yang ditentukan sebelum memulai perhitungan dan iterasi. Pada penelitian ini peneliti menetapkan jumlah klaster(c) yang terbentuk sebanyak tiga, disertai dengan pangkat pembobot (w) dua dan maksimal iterasi (MaxIter)sebesar 100 kemudian dengan error terkecil yangdiharapkan $(\zeta)$ sebesar 0,0001 .

\section{Inisialisasi Derajat Keanggotaan}

Pada Algoritma fuzzy c-meansderajat keanggotaan untuk perhitungan pada iterasi pertama ditentukan secara random atau acak bersyarat yaitu total derajat keanggotaan $\sum \mu_{i j}=1$ dan n merupakan banyak sampel data dimana pada penelitian ini peneliti menggunakan 200 data, $\mathrm{i}=1,2, \ldots, n$; sedangkan $\mathrm{j}$ sebanyak jumlah klaster, $\mathrm{j}=1,2, \ldots, \mathrm{c}$. Berikut sebagian dari derajat keanggotaan yang ditentukan secara acak oleh peneliti.

Tabel 3. Derajat Keanggotaan

\begin{tabular}{crrrr}
\hline No. & \multicolumn{1}{c}{$\boldsymbol{c}$} & \multicolumn{1}{c}{$\boldsymbol{c}$} & \multicolumn{1}{c}{ 3 } & Jumlah \\
\hline 1 & 0.1 & 0.3 & 0.6 & 1 \\
2 & 0.2 & 0.4 & 0.4 & 1 \\
3 & 0.6 & 0.2 & 0.2 & 1 \\
4 & 0.7 & 0.1 & 0.2 & 1 \\
5 & 0.5 & 0.3 & 0.2 & 1 \\
6 & 0.2 & 0.2 & 0.6 & 1 \\
7 & 0.3 & 0.6 & 0.1 & 1 \\
8 & 0.8 & 0.1 & 0.1 & 1 \\
9 & 0.3 & 0.4 & 0.3 & 1 \\
10 & 0.4 & 0.3 & 0.3 & 1 \\
11 & 0.5 & 0.1 & 0.4 & 1 \\
12 & 0.8 & 0.1 & 0.1 & 1 \\
13 & 0.2 & 0.4 & 0.4 & 1 \\
14 & 0.6 & 0.1 & 0.3 & 1 \\
15 & 0.3 & 0.5 & 0.2 & 1 \\
\hline
\end{tabular}

4. Hitung titik pusat klaster

Titik pusat klaster atau centroid pada fuzzy c means ditentukan dengan menggunakan rumus (6). Berikut tabel hasil perhitungan titik pusat klaster. 
Tabel 4. Titik Pusat Iterasi 1

\begin{tabular}{clc}
\hline Centroid cluster & \multicolumn{1}{c}{$\boldsymbol{X}$} & \multicolumn{1}{c}{$\boldsymbol{Y}$} \\
\hline c1 & 50.29894 & 53.44322 \\
c2 & 31.43617 & 52.92853 \\
c3 & 53.719 & 43.78028 \\
\hline
\end{tabular}

5. Perbarui derajat keanggotaan

Setelah menemukan pusat klaster, derajat keanggotaan akan dihitung kembali dengan menggunakan persamaan (7). Jarak antara data $x$ dengan titik pusat klaster perlu dihitung dalam menggunakan persamaan (7) yang dapat dilakukan dengan persamaan(8).Berbeda dengan derajat keanggotaan pada inisialisasi sebelum memulai iterasi dimana derajat keanggotaan ditentukan secara acak dengan ketentuan bahwa jumlahnya sama dengan satu. Pada iterasi setelah iterasi pertama, derajat keanggotaan diperoleh melalui kalkulasi dengan persamaan (7). Berikut derajat keanggotaan yang baru pada iterasi pertama yang digunakan untuk iterasi berikutnya.

Tabel 5. Derajat keanggotaan baru

\begin{tabular}{rlrrr}
\hline No. & \multicolumn{1}{c}{$\boldsymbol{c}$} & \multicolumn{1}{c}{$\boldsymbol{c}$} & \multicolumn{1}{c}{$\boldsymbol{c}$ 3 } & Jumlah \\
\hline 1 & 0.320453 & 0.195967 & 0.48358 & 1 \\
2 & 0.417292 & 0.265016 & 0.317692 & 1 \\
3 & 0.395994 & 0.253434 & 0.350572 & 1 \\
4 & 0.322794 & 0.483251 & 0.193955 & 1 \\
5 & 0.099523 & 0.834415 & 0.066062 & 1 \\
6 & 0.257051 & 0.416931 & 0.326018 & 1 \\
7 & 0.248772 & 0.556937 & 0.194291 & 1 \\
8 & 0.559957 & 0.127146 & 0.312897 & 1 \\
9 & 0.158018 & 0.059757 & 0.782225 & 1 \\
10 & 0.302907 & 0.193822 & 0.503272 & 1 \\
11 & 0.404614 & 0.25867 & 0.336716 & 1 \\
12 & 0.284265 & 0.323756 & 0.391979 & 1 \\
13 & 0.213541 & 0.605691 & 0.180768 & 1 \\
14 & 0.253318 & 0.20798 & 0.538702 & 1 \\
15 & 0.22968 & 0.550137 & 0.220183 & 1
\end{tabular}

\section{Fungsi Objektif}

Persamaan (5) digunakan untuk menghitung fungsi objektif pada setiap iterasi. Fungsi objektif dari setiap iterasi akan berubah dan selisih perubahan akan semakin mengecil. Ketika selisih fungsi objektif pada iterasi ke-n lebih kecil atau sama dengan epsilon (error terkecil yang diharapkan) yang telah ditentukan pada inisialisasi parameter maka iterasi akan berhenti. Fungsi objektif untuk iterasi pertama adalah 11813.91735 dengan selisih 
AITI: Jurnal Teknologi Informasi

Volume 16 No. 1 Februari 2019, 31-48

11813.91735 karena iterasi pertama maka selisihnya sama besar dengan fungsi objektifnya.

7. Iterasi

Ketika kondisi tidak terpenuhi maka iterasi dilakukan hingga kondisi terpenuhi dengan mengulangi proses pada tahap ke 4 sampai 6 . Pada penelitian ini peneliti menentukan maksimal iterasi sebanyak 100 kali iterasi maka kondisi untuk berhenti melakukan iterasi pada fuzzy cmeans dalam penelitian adalah ketika maksimal iterasi tercapai atau selisih fungsi objektif sebesar epsilon yang telah ditentukan pada inisialisasi parameter awal.

\section{B. Hasil Clustering Dengan 3 Klaster}

Proses clustering dengan fuzzy c-means dengan 3 klaster dengan 200 sampel data lokasi gerai PT. XYZ menggunakan koordinat kartesius telah membentuk 3 titik pusat klaster yang diperoleh dengan 100 kali proses iterasi atau mencapai batas maksimal iterasi yang telah ditentukan peneliti pada inisialisasi parameter awal.

Proses clustering dan ilustrasi hasil proses menggunakan Mathlab untuk menunjukkan plotatau grafik menggunakan sumbu $\mathrm{x}$ dan sumbu $\mathrm{y}$ untuk menampilkan hasil proses clustering dengan fuzzy c-means berupa centroid dengan pengelompokkan data ke dalam masing-masing klaster dan perubahan fungsi objektif pada iterasi yang dilakukan.

Fungsi objektif hasil proses pada iterasi ke-100 adalah 81812.513925 dan fungsi objektif pada iterasi ke-99 adalah 81812.791612 maka selisih fungsi objektif yang diperoleh sebesar 0.277687. Gambar 6 menampilkan plot data ilustrasi fuzzy c means pada penelitian ini.

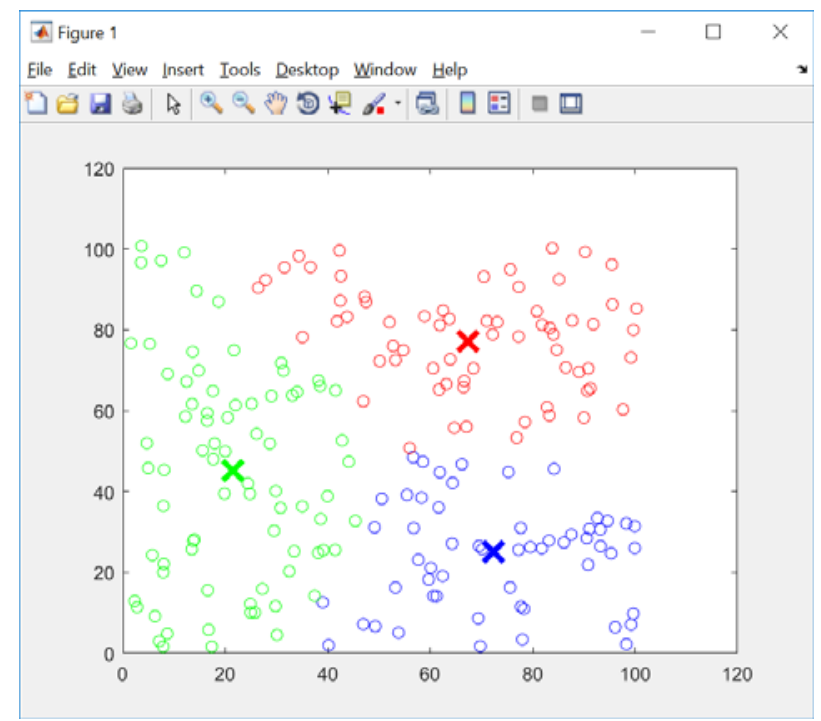

Gambar 6. Hasil fuzzy c means 3 klaster 
Klaster 1 diberi warna hijau, klaster 2 diberi warna merah, dan klaster 3 berwarna biru. Hasil proses fuzzy c-means pada iterasi ke-100 mendapatkan centroid masing masing klaster sebagai berikut:

Tabel 6. Titik Pusat 3 klaster Iterasi 100

\begin{tabular}{lcl}
\hline centroid & $\boldsymbol{X}$ & \multicolumn{1}{c}{$\boldsymbol{Y}$} \\
\hline C1 & 21.57011 & 44.698 \\
C2 & 67.07408 & 77.34299 \\
C3 & 72.65572 & 25.21317 \\
\hline
\end{tabular}

Perubahan fungsi objektif pada setiap iterasi diilustrasikan dengan gambar 7 menggunakan plot untuk menunjukkan perubahan fungsi objektif dari iterasi ke iterasi berikutnya semakin mengecil selisihnya. Selisih fungsi objektif semakin mendekati epsilonyang ditentukan pada inisialisasi awal.

Setiap centroid pada masing-masing klaster mewakili lokasi gudang pendukung untuk gerai-gerai PT. XYZ. Titik berwarna hijau, biru, dan merah pada Gambar 6 mewakili lokasi gerai berdasarkan koordinat kartesius yang telah dimasukkan. Sekumpulan gerai tersebut didukung oleh gudang pendukung yang telah dikelompokkan berdasarkan derajat keanggotaan yang paling besar pada tiap datapada iterasi terakhir hasil clustering. Berikut sebagian data hasil pengelompokkan dengan fuzzy c means.

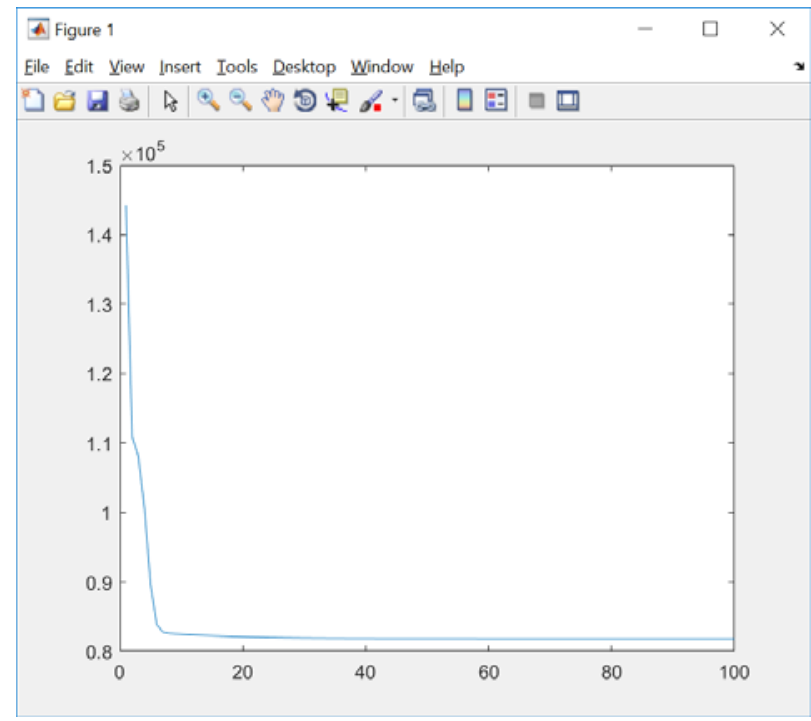

Gambar 7. plot fungsi objektif

Tabel 7. Sampel Penentuan Klaster

\begin{tabular}{lcccr}
\hline No. & $\boldsymbol{\mu 1}$ & $\boldsymbol{\mu 2}$ & $\boldsymbol{\mu 3}$ & \multicolumn{1}{c}{ Klaster } \\
\hline 1 & 0.485223 & 0.362905 & 0.151872 & 1 \\
2 & 0.973695 & 0.011472 & 0.014832 & 2 \\
3 & 0.012739 & 0.017048 & 0.970213 & 3 \\
4 & 0.925417 & 0.037604 & 0.036979 & 1 \\
5 & 0.064438 & 0.107743 & 0.827819 & 3 \\
\hline
\end{tabular}


AITI: Jurnal Teknologi Informasi

Volume 16 No. 1 Februari 2019, 31-48

\begin{tabular}{lrrrr}
\hline No. & \multicolumn{1}{c}{$\boldsymbol{\mu 1}$} & $\boldsymbol{\mu} \boldsymbol{2}$ & $\boldsymbol{\mu} \mathbf{3}$ & \multicolumn{1}{c}{ Klaster } \\
\hline 6 & 0.077945 & 0.741817 & 0.180238 & 2 \\
7 & 0.837419 & 0.102263 & 0.060317 & 1 \\
8 & 0.45344 & 0.395015 & 0.151544 & 1 \\
9 & 0.226445 & 0.321887 & 0.451667 & 3 \\
10 & 0.090198 & 0.850631 & 0.059171 & 2 \\
11 & 0.370409 & 0.12555 & 0.50404 & 3 \\
12 & 0.07148 & 0.117003 & 0.811517 & 3 \\
13 & 0.016903 & 0.024957 & 0.95814 & 3 \\
14 & 0.037605 & 0.058772 & 0.903622 & 3 \\
15 & 0.711169 & 0.097424 & 0.191407 & 1 \\
\hline
\end{tabular}

\section{Hasil Clustering Dengan 4 klaster}

Proses fuzzy c-means dengan 4 klaster dengan 200 sampel data lokasi gerai PT. XYZ menggunakan koordinat kartesiusdan epsilon yang sama akan membentuk 4 titik pusat klaster yang diperoleh dengan batas maksimal iterasi adalah 100 kali proses iterasi atau mencapai batas maksimal iterasi yang telah ditentukan peneliti pada inisialisasi parameter awal. Dilakukan clustering dengan 4 klaster untuk menunjukkan perbedaan letak centroiddan pengelompokkan data ke dalam klaster.

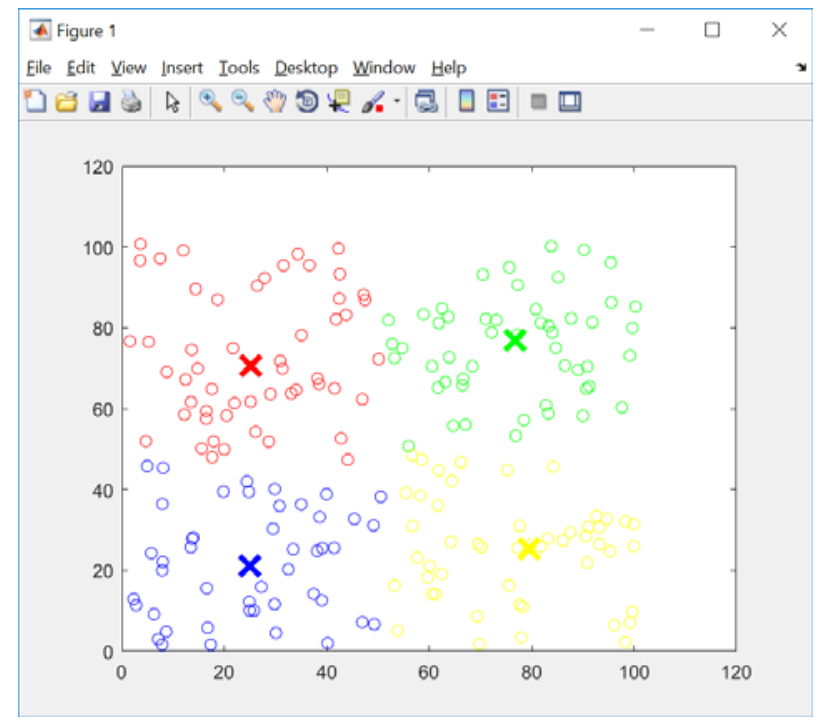

Gambar 8. Hasil fuzzy c-means 4 klaster

Pada proses fuzzy c-means dengan 4 klaster diperoleh hasil berbeda dimana iterasi hanya terjadi sebanyak 39 kali iterasi. Fungsi objektif pada iterasi ke 39 adalah 50396.663884 dan pada iterasi ke 38 adalah 50396.663890 sehingga selisih fungsi objektif sebesar0.000006.

Terdapat 4 titik pusat klaster mengikuti jumlah klaster yang merupakan lokasi gudang pendukung berdasarkan koordinat kartesius dari setiap centroid.Klaster 1 diberi warna biru, klaster 2 diberi warna merah, klaster 3 
berwarna hijau, dan klaster 4 berwarna kuning. Hasil proses fuzzy c-means mendapatkan centroid masing masing klaster sebagai berikut:

Tabel 8. Titik Pusat 4 klaster

\begin{tabular}{lll}
\hline centroid & $\boldsymbol{X}$ & $\boldsymbol{Y}$ \\
\hline C1 & 25.0438 & 21.0522 \\
C2 & 25.2055 & 70.7366 \\
C3 & 76.7582 & 76.8634 \\
C4 & 79.5112 & 25.3190 \\
\hline
\end{tabular}

Perubahan fungsi objektif untuk 4 klaster pada setiap iterasi diilustrasikan dengan gambar 9 menggunakan plot.

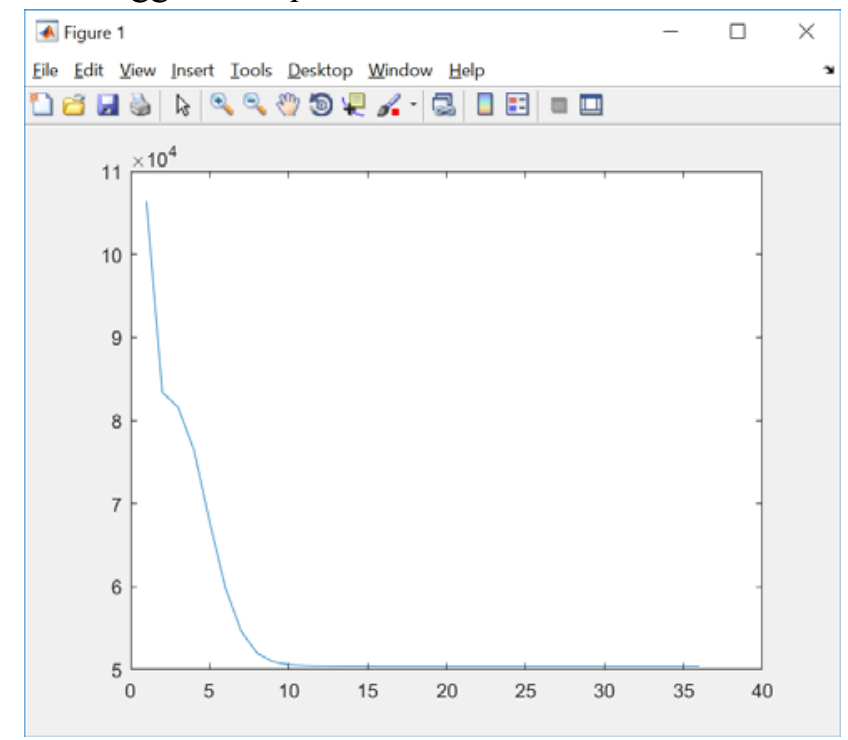

Gambar 9. Plot fungsi objektif 4 klaster

Tabel 9. Sampel Penentuan Klaster dengan 4 Klaster

\begin{tabular}{rrrrrr}
\hline No. & \multicolumn{1}{c}{$\boldsymbol{\mu 1}$} & $\boldsymbol{\mu} \mathbf{2}$ & $\boldsymbol{\mu 3}$ & $\boldsymbol{\mu 4}$ & Klaster \\
\hline 1 & 0.11375 & 0.133141 & 0.686065 & 0.067043 & 3 \\
2 & 0.651741 & 0.053818 & 0.225342 & 0.069099 & 1 \\
3 & 0.00029 & 0.000338 & 0.000176 & 0.999197 & 4 \\
4 & 0.443537 & 0.068412 & 0.417129 & 0.070922 & 1 \\
5 & 0.035715 & 0.059517 & 0.025381 & 0.879387 & 4 \\
6 & 0.026805 & 0.846417 & 0.04241 & 0.084368 & 2 \\
7 & 0.053598 & 0.027103 & 0.900261 & 0.019037 & 3 \\
8 & 0.106959 & 0.142963 & 0.68308 & 0.066997 & 2 \\
9 & 0.179235 & 0.272001 & 0.196575 & 0.352188 & 4 \\
10 & 0.073912 & 0.484937 & 0.355941 & 0.085211 & 2 \\
11 & 0.672044 & 0.057308 & 0.080399 & 0.190249 & 1 \\
12 & 0.043314 & 0.070031 & 0.030499 & 0.856156 & 4 \\
13 & 0.012002 & 0.016375 & 0.007951 & 0.963672 & 4 \\
\hline
\end{tabular}


AITI: Jurnal Teknologi Informasi

Volume 16 No. 1 Februari 2019, 31-48

\begin{tabular}{rcrrrr}
\hline No. & $\boldsymbol{\mu 1}$ & $\boldsymbol{\mu} \mathbf{2}$ & $\boldsymbol{\mu 3}$ & $\boldsymbol{\mu 4}$ & Klaster \\
\hline 14 & 0.012212 & 0.018166 & 0.008239 & 0.961383 & 4 \\
15 & 0.933271 & 0.012866 & 0.03047 & 0.023393 & 1 \\
\hline
\end{tabular}

Pada pengujian jumlah iterasi yang dilakukan tidak selalu sama hal ini dikarenakan derajat keanggotaan yang ditentukan secara acak sehingga fungsi objektif berbeda, namun letak centroid tetap sama hanya klasternya dapat berbeda.

\section{Simpulan}

Berdasarkan pembahasan pada bab sebelumnya maka proses clustering dengan menggunakan fuzzy c-means dapat mengelompokkan data gerai dengan gudang pendukung tanpa menentukan lokasi awal gudang pendukung tersebut. Lokasi gerai PT. XYZ terlebih dahulu diubah menjadi koordinat kartesiusdimana terdapat koordinat pada sumbu $\mathrm{x}$ dan $\mathrm{y}$. Proses fuzzy c-means dilakukan dengan perhitungan fungsi objektif dan derajat keanggotaan yang ditentukan secara acak pada inisialisasi parameter awal dan dilakukan sampai kondisi terpenuhi yaitu sebanyak maksimal iterasi atau sampai selisih fungsi objektifsebesar atau mendekatiepsilon yang telah ditentukan pada inisialisasi. Semakin kecil epsilon maka semakin akurat hasil fuzzy c-means.

Pusat klaster atau centroid terakhir hasil dari fuzzy c-means berupa koordinat kartesiusyang dekat dengan sekumpulan gerai menjadi acuan untuk lokasi pendirian gudang pendukung. Iterasi yang dilakukan dalam proses membuat centroid tiap klaster mengarah keposisi yang dekat dengan sekumpulan gerai yang dikelompokkan dalam klaster yang terbentuk. Sejumlah gerai yang didukung oleh gudang tersebut ditentukan melalui pengelompokkan hasil clustering fuzzy cmeansberdasarkan derajat keanggotaan tertinggi dari sejumlah klaster yang ada.Hasil clustering fuzzy c means dengan 4 klaster memerlukan iterasi yang lebih sedikit daripada 3 klaster, karena menggunakan derajat keanggotaan yang acak maka jumlah iterasi tidak selalu sama.

Penelitian selanjutnya dapat berfokus mendapatkan hasil yang lebih akurat dari fuzzy c-means maka penentuan epsilon sebagai kondisi berhenti perlu diperhatikan. Maksimal Iterasi yang diinisialisasikan jika semakin besar maka selisih fungsi objektif akan semakin mendekati epsilon sehingga semakin akurat, namun akan berdampak pada lama proses dikarenakan banyaknya iterasi yang dilakukan.

\section{Daftar Pustaka}

[1] Merliana, Ernawati and Santoso, “Analisa Penentuan Jumlah Cluster Terbaik Pada Metode K-means Clustering," in Prosiding Seminar Nasional Multi disiplin ilmu \& call for papers Unisbank, 2016.

[2] Lindawati, "Data Mining Dengan Teknik Clustering Dalam Pengklasifikasian Data Mahasiswa Studi Kasus Prediksi Lama Studi 
Mahasiswa Universitas Bina Nusantara," Seminar Nasional Informatika, vol. 5, no. 1, 2008.

[3] T. Meri, L. Linawati and A. Setiawan, "Penerapan Algoritma Fuzzy C-Means (FCM) Pada Penentuan Lokasi Pendirian Loket Pembayaran Air PDAM Salatiga," Prosiding Seminar Nasional Sains dan Pendidikan Sains, vol. 4, no. 1, pp. 497 - 505, 2013.

[4] H. Sulastri and A. Irham, "PENERAPAN DATA MINING DALAM PENGELOMPOKAN PENDERITA," Jurnal Teknologi dan Sistem Informasi, vol. 3, no. 2, pp. 209-305, 2017.

[5] J. C. Bezdek, R. Ehrlich and W. Full, "FCM: the fuzzy c-means clustering algorithm," Comput, Geosci, vol. 10, no. 2, pp. 191-203, 1984.

[6] E. Prasetyo, Data Mining, Mengolah Data Menjadi Informasi Menggunakan Matlab, Yogyakarta: Penerbit Andi, 2014.

[7] A. Kridanto and J. L. Buliali, "Metode Hibrida FCM dan PSO-SVR untuk Prediksi Data Arus Lalu Lintas," Jurnal Teknik Informatika dan Sistem Informasi, vol. 1, no. 3, pp. 302-311, 2015.

[8] S. Kusumadewi and H. Purnomo, Aplikasi Fuzzy Untuk Pendukung Keputusan, 2nd ed., Yogyakarta: Graha Ilmu, 2010.

[9] S. Kusumadewi and S. Hartati, Integrasi Sistem Fuzzy dan Jaringan Syaraf, 2nd ed., Yogyakarta: Graha Ilmu, 2010.

[10] P. Hartono and N. Fauzi, "Pengendali Otomasi 3-Axis Berbasis PC pada Simulasi Proses Las," Metal Indonesia, vol. 36, no. 1, 2014.

[11] S. Sastra, Permodelan 2D dan 3D dengan Autocad, Jakarta: PT. Elex Media Komputindo, 2009, pp. 195-197. 